\title{
Zapobieganie niepełnosprawności intelektualnej w świetle rozważań Amerykańskiego Stowarzyszenia Niepełnosprawności Intelektualnej i Rozwojowej (AAIDD)
}

\section{KEY WORDS}

intellectual disability, prevention,

prevention as a form of support, child with or without the risk of intellectual disability, parent - child interaction

\begin{abstract}
Kopeć Danuta, Zapobieganie niepełnosprawności intelektualnej w świetle rozważań Amerykańskiego Stowarzyszenia Niepełnosprawności Intelektualnej i Rozwojowej (AAIDD) [Prevention of Intellectual Disability in the Light of the Considerations of the American Association on Intellectual and Developmental Disabilities (AAIDD)]. Kultura - Społeczeństwo - Edukacja nr 2, 2012, Poznań 2012, pp. 61-74, Adam Mickiewicz University Press. ISBN 978-83232-2528-7

The long-awaited handbook by the special pedagogy educators issued by the Committee on Terminology and Classification of the American Association on Intellectual and Developmental Disabilities (Schalock et al, 2010) appeared finally in 2010. This article discusses the way of understanding the prevention of intellectual disability represented in the aforementioned handbook which is an expression of the position of the AAIDD. The analysis embraces these forms of intellectual disability for which the reference point is the early interpersonal interaction between the parent/guardian and the child at intellectual disability risk or the child with intellectual disability. These are simultaneously understood by the AAIDD as forms of support for parents and/or guardians of a child threatened with intellectual disability or a child with intellectual disability. The article concludes with findings drawn from the presented material.
\end{abstract}

W 2010 roku na amerykańskim rynku wydawniczym pojawił się od dawna oczekiwany podręcznik Komitetu ds. Terminologii i Klasyfikacji Amerykańskiego Stowarzyszenia Niepełnosprawności Intelektualnej i Rozwojowej (The American Association on Intellectual and Developmental Disabilities ad Hoc Committee on 
Terminology and Classification) (Schalock i inni, 2010)1. Poruszane w nim zagadnienia są ważne przede wszystkim dla tego obszaru pedagogiki specjalnej, który dotyczy osoby z niepełnosprawnością intelektualną i szeroko rozumianej przestrzeni jej funkcjonowania, społecznej, edukacyjnej oraz rehabilitacyjnej (por. Olszewski, Parys, Trojańska, 2012) z następujących powodów. Po pierwsze podręcznik zawiera ustalenia terminologiczne istotne dla trwającego, również w obszarze polskiej pedagogiki specjalnej, sporu dotyczącego prawidłowości stosowania terminu 'upośledzenie umysłowe' verus 'niepełnosprawność intelektualna' (por. Wlazło, 2005; Krause, 2009). Autorzy podręcznika wypowiadają się w nim jednoznacznie za stosowaniem terminu 'niepełnosprawność intelektualna' ${ }^{2}$ (Schalock, 2010: 3-25). Po drugie Schalock i jego zespół rozpatrują problematykę niepełnosprawności intelektualnej w kontekście bioekologicznej teorii systemów Urie Boronfenbrennera (1979, 2005; 2010: 17-19, 177-178). Powyższa teoria stanowi dla autorów podręcznika konceptualny konstrukt służący do analizy: a) etiologii niepełnosprawności intelektualnej, b) zapobiegania niepełnosprawności intelektualnej, c) form wsparcia oferowanych zarówno osobie z niepełnosprawnością intelektualną, jak i osobom z jej najbliższego otoczenia (Schalock, 2010: 18-19, 123-134).

Celem mojego artykułu nie jest analiza wszystkich zawartych w podręczniku AAIDD, skądinąd bardzo intersujących, zagadnień. Chciałabym skupić się przede wszystkim na tych $\mathrm{z}$ nich, które są związane z prewencją wystąpienia niepełnosprawności intelektualnej u osoby w odniesieniu do trzech wymiarów czasowych jej egzystencjalnego istnienia, a mianowicie do okresu: prenatalnego, perinatalnego oraz postnatalnego. Przedstawię je w tekście według następującego porządku: najpierw zaprezentuję sposób rozumienia zapobiegania niepełnosprawności intelektualnej w kontekście podręcznika AAIDD. Następnie przedstawię egzemplifikację tych form zapobiegania niepełnosprawności intelektualnej, dla których odniesieniem jest wczesna relacja interpersonalna pomiędzy rodzicem/opiekunem a dzieckiem zagrożonym niepełnosprawnością intelektualną lub dzieckiem $\mathrm{z}$ niepełnosprawnością intelektualną. W zakończeniu przedstawię wnioski wypływające $\mathrm{z}$ prezentowanego przeze mnie materiału.

${ }^{1}$ Pojawienie się podręcznika poprzedzały artykuły referujące postępy pracy nad nim (por. Schalock i inni, 2007; Wehmeyer i inni, 2008).

${ }^{2} \mathrm{Na}$ uwagę zasługuje fakt, iż propozycja AAIDD dotycząca terminu „,niepełnosprawność intelektualna" zostanie uwzględniona w najnowszych klasyfikacjach ICD-11, w której również będzie stosowany termin 'niepełnosprawność intelektualna' zamiast dotychczas stosowanego 'upośledzenie umysłowe' (Salvador-Carulla, 2011). 


\section{Płaszczyzny zapobiegania niepełnosprawności intelektualnej w świetle podręcznika AAIDD}

Komitet ds. Terminologii i Klasyfikacji AAIDD rozpatruje zapobieganie ${ }^{3}$ niepełnosprawności intelektualnej osoby w kontekście trzech płaszczyzn, których nie należy analizować w separacji. Ich holistyczne ujmowanie warunkuje dostrzeżenie wielowymiarowości, która jest wpisana w proces zapobiegania niepełnosprawności intelektualnej. W poszczególnych płaszczyznach zwraca się uwagę na:

- stopień zapobiegania niepełnosprawności intelektualnej - płaszczyzna pierwsza;

- wpływ czynnika warunkującego niepełnosprawność intelektualną w przebiegu całego życia osoby - płaszczyzna druga;

- zapobieganie jako forma wsparcia, tzw. wsparcie zapobiegawcze ${ }^{4}$ - płaszczyzna trzecia (Schalock i inni, 2010: 123-129).

Poniżej scharakteryzuję każdą z wyżej wyróżnionych płaszczyzn.

\section{Płaszczyzna pierwsza: stopień zapobiegania niepełnosprawności intelektualnej}

W ramach płaszczyzny pierwszej zwraca się uwagę na stopnie zapobiegania niepełnosprawności intelektualnej, których idea została zaczerpnięta z obszaru medycyny (por. Schalock i inni, 2010: 123). Wyróżnia się trzy stopnie zapobiegania niepełnosprawności intelektualnej: pierwszy, drugi i trzeci ${ }^{5}$ (por. Schalock i inni, 2010: 123).

W ramach zapobiegania niepełnosprawności intelektualnej pierwszego stopnia dąży się do tego, by nie doszło do jej pojawienia się, np. wspiera się ciężarne kobiety dotknięte chorobą alkoholową w zachowaniu trzeźwości (Schalock i inni, 2010: 124). Należy pamiętać, że dla AAIDD egzemplifikacją tego działania nie jest aborcja eugeniczna ani selektywny wybór zarodków, będący skutkiem diagnostyki preimplantacyjnej. Zapobieganie niepełnosprawności intelektualnej pierwszego stopnia jest bowiem zawsze związane $\mathrm{z}$ istnieniem osoby i dążeniem do tego, by nie została ona dotknięta niepełnosprawnością intelektualną (Schalock i inni, 2010: 126).

Zapobieganie drugiego stopnia dotyczy przede wszystkim osób dotkniętych schorzeniem, najczęściej uwarunkowanym genetycznie, któremu nie można bez-

\footnotetext{
${ }^{3} \mathrm{~W}$ jęz. ang. prevention.

${ }^{4} \mathrm{~W}$ jęz. ang. prevention supports.

${ }^{5} \mathrm{~W}$ jęz. ang.: primary, secondary, tertiary prevention.
} 
pośrednio zapobiec. Jego egzemplifikacją jest między innymi fenyloketonuria (PKU), wrodzona choroba metaboliczna, w której następuje kumulacja aminokwasu fenyloanaliny (Phe) we krwi i płynach tkankowych. Przyczyną fenyloketonurii jest brak enzymu hydroksylazy fenyloanaliny (PAH) lub deficyt enzymów uczestniczących $\mathrm{w}$ syntezie i cyklicznym odtwarzaniu tetrahydrobiopteryny $\left(\mathrm{BH}_{4}\right)$ (Mowszet, Hutyra, 2008: 201-202). Zahamowanie przemiany Phe z powodu niedoboru PAH powoduje gromadzenie się jej oraz produktów ubocznych przemiany tego aminokwasu w płynach ustrojowych osoby. Rezultatem zaburzeń równowagi aminokwasowej jest uszkodzenie ośrodkowego układu nerwowego, którego przejawem są zaburzenia i opóźnienia mielinizacji włókien nerwowych oraz zmniejszenia masy mózgu, które warunkuje wystąpienie niepełnosprawności intelektualnej osoby (Mowszet, Hutyra, 2008: 205; Schalock i inni, 2010: 124-125). Należy pamiętać, że fenyloketonuria ${ }^{6}$ będzie towarzyszyła osobie przez całe jej życie. Ekspresji mutacji genu hydroksylazy fenyloalaniny ${ }^{7}$ skutecznie zapobiega odpowiednia dieta niskofenyloalaninowa, która zapobiega uszkodzeniu ośrodkowego układu nerwowego. Można ją traktować jako egzemplifikację zapobiegania drugiego stopnia. Kolejnym przykładem zapobiegania w odniesieniu do fenyloketonurii są badania przesiewowe noworodków w jej kierunku (Mowszet, Hutyra, 2008; Schalock i inni, 2010: 124). Zdaniem Schalocka i jego zespołu nieetycznie są jednak badania przesiewowe proponowane tym osobom, u których nie pojawia się symptomatologia charakterystyczna dla danego schorzenia uwarunkowanego genetycznie, które to schorzenie, w kontekście obecnego stanu wiedzy, nie poddaje się leczeniu (Mowszet, Hutyra, 2008; Schalock i inni, 2010: 124$)^{8}$.

W ramach zapobiegania trzeciego stopnia należy rozpatrywać strategie, które zmniejszają, ale nie mogą całkowicie zapobiec konsekwencjom niepełnosprawności osoby, jak również konsekwencjom jej niepełnosprawności intelektualnej. Zapobieganie trzeciego stopnia dąży bowiem do poprawy ogólnego funkcjonowania osoby rozpatrywanego w kontekście modelu WHO (Schalock i inni, 2010: 125). Strategiami będącymi egzemplifikacją zapobiegania trzeciego stopnia są między innymi: a) okresowe badania tarczycy u osób z zespołem

\footnotetext{
${ }^{6}$ Uwaga ta dotyczy również innych chorób uwarunkowanych genetycznie.

${ }^{7}$ Genu hydroksylazy fenyloalaniny jest zlokalizowany na długim ramieniu chromosomu 12 (12q22-24.1) (Mowszet, Hutyra, 2008: 202).

8 „Nancy Wexler obawia się, że nauka jest teraz w sytuacji Tejrezjasza, niewidomego wieszcza tebańskiego. (...). Widzenie przyszłości było (...) straszliwy losem - widział ją, ale nie był w stanie jej zmienić. «Jest tylko żałością - powiedział Tejrezjasz do Edypa - być mądrym, kiedy mądrość nie przynosi korzyści». Albo, jak to ujmuje Wexler, «Czy chcesz wiedzieć, kiedy umrzesz, szczególnie jeśli nie możesz na to wpłynąć» (Ridley, 2001: 74-75). O dylematach etycznych związanych ze stosowaniem testów DNA w diagnostyce chorób nowotworowych z perspektywy socjologicznej pisze Siemińska (2010).
} 
Downa, których celem jest zapobieżenie rozwojowi choroby; b) wsparcie w procesie redukowania zachowań problemowych osoby oraz podczas poszukiwania innych dróg wyrażania siebie; c) strategie sprzyjające integracji społecznej (Schalock i inni, 2010: 125)

\section{Płaszczyzna druga: wpływ czynnika warunkującego niepełnosprawność intelektualna na przebieg całego życia osoby}

Zdaniem Schalocka i jego zespołu znajomość czynników ryzyka niepełnosprawności intelektualnej, które oddziaływują na osobę w przebiegu jej całego życia, tj. od chwili poczęcia aż do momentu śmierci, są bardzo istotne dla efektywnego projektowania wsparcia zapobiegawczego dla niej (Schalock i inni, 2010: 127). Zespół Schalocka wyróżnił cztery kategorie czynników ryzyka niepełnosprawności intelektualnej, a mianowicie czynniki:

a) biomedyczne, dotyczące biologicznego aspektu funkcjonowania człowieka9;

b) społeczne dotyczące społecznego (relacyjnego) aspektu funkcjonowania człowieka $^{10}$;

c) związane ze sposobem funkcjonowania rodziców i/lub opiekunów, które może mieć negatywny wpływ na dziecko ${ }^{11}$;

d) związane z dostępnością do wsparcia edukacyjnego, które wpływa na stan wiedzy rodziców i ich poziom umiejętności rodzicielskich ${ }^{12}$ (Schalock i inni, 2010: 61, 131).

Należy pamiętać, że strategie wsparcia zapobiegawczego, które uwzględniają oddziaływanie tylko jednego czynnika, mogą okazać się nieskuteczne i nieprzydatne $\mathrm{w}$ odniesieniu do biografii konkretnej osoby z niepełnosprawnością intelektualną (Schalock i inni, 2010: 127). Dlatego też ważne jest uwzględnianie wzajemnej interakcji, jaka zachodzi pomiędzy poszczególnymi czynnikami ryzyka ${ }^{13}$ (Schalock i inni, 2010: 131).

${ }^{9}$ W jęz. ang. Biomedical. Wśród nich wyróżnia się, między innymi: mutacje pojedynczego genu, zespoły chromosomowe, zaburzenia metaboliczne, choroby matki, wiek rodziców (Schalock i inni, 2010: 60).

${ }^{10} \mathrm{~W}$ jęz. ang. Social. Wśród nich wyróżnia się, między innymi: ubóstwo, złą dietą matki, przemoc w rodzinie, brak dostępu do opieki prenatalnej (Schalock i inni, 2010: 60).

${ }^{11} \mathrm{~W}$ jęz. ang. Behavioral. Wśród nich wyróżnia się, między innymi: używanie różnych używek (papierosów, alkoholu, narkotyków) przez matkę lub przez obydwoje rodziców (Schalock i inni, 2010: 60).

${ }^{12} \mathrm{~W}$ jęz. ang. Educational. Wśród nich wyróżnia się, między innymi: niskie funkcjonowanie poznawcze rodziców pozbawionych wsparcia, brak przygotowania do sprawowania funkcji rodzica (Schalock i inni, 2010: 60).

${ }^{13} \mathrm{~W}$ jęz. ang. Interactions among risk factors (Schalock i inni, 2010: 60). 


\section{Płaszczyzna trzecia: zapobieganie jako forma wsparcia}

Schalock i jego zespół do dotychczasowego myślenia o wsparciu, reprezentowanego przez AAIDD, a wcześniej AAMR ${ }^{14}$, wprowadził pojęcie wsparcia zapobiegawczego $^{15}$ (2010: 128-131). Skonstruowany przez siebie model zapobiegania niepełnosprawności intelektualnej nazwali modelem wieloczynnikowym i międzypokoleniownym ${ }^{16}$ (Schalock i inni, 2010: 130). Zostały w nim wyróżnione dwa wymiary. Pierwszy, związany ze stopniem zapobiegania, tj. zapobieganiem pierwszego, drugiego i trzeciego stopnia oraz beneficjentem zapobiegania $w$ ramach każdego z wyróżnionych przez siebie stopni zapobiegania. Na uwagę zasługuje fakt, że $\mathrm{w}$ ramach zapobiegania pierwszego stopnia jego odbiorcą jest zarówno dziecko zagrożone niepełnosprawnością intelektualną lub dziecko z niepełnosprawnością intelektualną, jak i rodzice i/lub opiekunowie dziecka zagrożonego niepełnosprawnością intelektualną lub dziecka z niepełnosprawnością intelektualną. Zapobieganie drugiego i trzeciego stopnia jest skierowane do osoby z niepełnosprawnością intelektualną na różnych etapach jej życia. Drugi wymiar odnosi się do czynników wsparcia, których kategorie są tożsame z czynnikami ryzyka wystąpienia niepełnosprawności intelektualnej. W modelu zostały wyróżnione następujące czynniki wsparcia: a) biomedyczne, b) społeczne, c) związane ze sposobem funkcjonowania rodziców i/lub opiekunów, d) związane z dostępnością do wsparcia edukacyjnego (Schalock i inni, 2010: 130).

Dla wsparcia zapobiegawczego istotną rolę odgrywa proces układania planu działania, które ma skutkować wparciem zapobiegawczym skierowanym do konkretnej osoby. Schalock z zespołem wyróżnili w nim trzy kroki, które poniżej scharakteryzuję, opierając się na zaproponowanym przez nich przykładzie dziecka $\mathrm{z}$ alkoholowym zespołem płodowym (FAS: Fetal Alcohol Syndrome) (2010: 131-133).

Krok pierwszy to stworzenie kompleksowego programu wsparcia. W jego ramach należy opisać wszystkie kategorie czynników ryzyka warunkujących niepełnosprawność konkretnego dziecka, jak również wzajemnego oddziaływanie pomiędzy poszczególnymi czynnikami. I tak w odniesieniu do dziecka z FAS będą to następujące czynniki:

- biomedyczne: alkoholowy zespół płodowy, wrodzona wada serca;

- społeczne: ubóstwo rodziny, bezdomność, nieodpowiednie umiejętności wychowawcze;

14 The American Association on Mental Retardation (AAMR) - Amerykańskie Stowarzyszenie Upośledzenia Umysłowego, które w 2006 roku zmieniło nazwę na The American Association on Intellectual and Developmental Disabilities, tj. Amerykańskie Stowarzyszenie Niepełnosprawności Intelektualnej i Rozwojowej (AAIDD) (Deutsch, Smith, 2008, t.1.: 225).

${ }^{15} \mathrm{~W}$ jęz. ang. prevention supports.

${ }^{16} \mathrm{~W}$ jęz. ang. A mulitfactorial and intergerational Model. 
- związane z funkcjonowaniem rodziców: nadużywanie alkoholu, zaniedbywanie dziecka;

- związane z dostępnością do wsparcia edukacyjnego: brak możliwości korzystania z ośrodka wczesnej interwencji (Schalock i inni, 2010: 131).

Interakcję pomiędzy poszczególnymi czynnikami ryzyka można opisać w następujący sposób: po pierwsze, nadużywanie alkoholu przez matkę oraz brak jej wiedzy na temat opieki prenatalnej skutkują pojawieniem się u dziecka FAS; po drugie, bezdomność matki dziecka skutkuje brakiem objęcia dziecka oddziaływaniami związanymi z wczesną interwencją (Schalock i inni, 2010: 131).

Krok drugi polega na dokładnym opisie strategii wsparcia zapobiegawczego dla każdego, wyróżnionego w ramach kroku pierwszego czynnika ryzyka niepełnosprawności intelektualnej. I tak dla czynnika:

- biomedycznego wsparciem będzie: leczenie wady serca, odpowiednie odżywianie;

- społecznego wsparciem będzie: wspieranie umiejętności rodzicielskich rodziców, wspieranie rodziców w pełnieniu ról rodzicielskich;

- związanego z funkcjonowaniem rodziców wsparciem będzie: leczenie alkoholizmu rodziców, zapobieganie przemocy w relacjach rodzinnych;

- związanego z dostępnością do wsparcia edukacyjnego wsparciem będzie: objęcie dziecka oddziaływaniem związanym z wczesną interwencją (Schalock i inni, 2010: 131).

Krok trzeci związany ze wsparciem zapobiegawczym polega na ciągłym monitorowaniu efektywności dotychczas wypracowanego planu postępowania w odniesieniu do dziecka oraz osób z jego najbliższego otoczenia oraz jego modyfikacji lub zmiany, gdy zajdzie taka potrzeba (Schalock i inni, 2010: 131).

\section{Zapobieganie niepełnosprawności intelektualnej rozpatrywane w kontekście wczesnej relacji interpersonalnej pomiędzy rodzicem a dzieckiem}

Wczesna relacja pomiędzy rodzicem a dzieckiem wyznacza tory dalszego rozwoju dziecka we wszystkich sferach jego funkcjonowania ${ }^{17}$ (por. Cozolino, 2004; Czub, 2005: 67-93; Siegel, 2009; Stawicka, 2008: 48-128; Gerhardt, 2010). Powyższa prawda, uznawana za oczywistą w obszarze badawczym dotyczącym psychologii

17 Zdaniem Gerhardt „[r]ozwój mózgu u dziecka zależy tak naprawdę od jego określonych doświadczeń z ludźmi - jest on niezwykle «zależny od doświadczenia», jak to ujęli badacze mózgu. Uzasadnienie takiego stanu rzeczy można znaleźć w procesie ewolucyjnym: w ten sposób człowiek potrafi dopasować się do środowiskowej niszy, w której się znajduje. (...). [K]iedy jesteśmy niemowlętami, nasze mózgi są programowane przez starszych członków społeczności, dzięki czemu dostosowujemy się do określonej rodziny i grupy społecznej, w której musimy żyć” (2010: 29). 
rozwojowej dziecka z normą intelektualną (por. ibidem), bywa, moim zdaniem, często pomijana w odniesieniu do dziecka zagrożonego niepełnosprawnością intelektualną i/lub dziecka $\mathrm{z}$ niepełnosprawnością intelektualną (por. Kościelska, 1995; Pisula, 2003; Pisula, 2007). Fakt ten powinien wzbudzić niepokój choćby $\mathrm{z}$ tego powodu, że pełnienie roli rodzica dziecka zagrożonego niepełnosprawnością intelektualną i/lub z niepełnosprawnością wymaga dodatkowych umiejętności rodzicielskich, które nie muszą być wpisane w rolę rodzica dziecka pełnosprawnego, a których brak może mieć nie tylko negatywne konsekwencje na przebieg relacji między rodzicem a dzieckiem, ale może również implikować pojawienie się u dziecka niepełnosprawności intelektualnej (Kościelska, 1995; Kościelska, 1998; Pisula, 2003; Pisula, 2007). Z tego powodu uważam za bardzo istotne dla praktyki i teorii pedagogicznej zwrócenie uwagi przez Schalocka i jego zespół na relację pomiędzy rodzicem a dzieckiem oraz udzielanie w jej kontekście wsparcia zapobiegawczego, którego celem jest uniemożliwienie zaistnienia niepełnosprawności intelektualnej dziecka (2010: 130). W związku z tym, że za nawiązanie relacji i jej przebieg zawsze odpowiedzialność ponosi dorosły z powodu posiadanych zasobów psychicznych (por. Cozollino, 2004; Siegel, 2009; Gerhardt, 2010), to właśnie on powinien być, i w propozycji Schalocka i jego zespołu jest, beneficjentem wsparcia zapobiegawczego oferowanego w kontekście wczesnej relacji z dzieckiem (Schalock i inni, 2010). Na uwagę zasługuje również fakt, że w myśleniu o wsparciu zapobiegawczym w kontekście wczesnej relacji pomiędzy rodzicem a dzieckiem jest brana po uwagę międzypokoleniowa transmisja wzorca przywiązania (por. Czub, 2005: 85). Każdy rodzic był przecież kiedyś dzieckiem, które wchodziło ze swoim rodzicem w określony typ relacji. Owa relacja zakorzeniona w biografii rodzica ma wpływ na sposób jego bycia z własnym dzieckiem ${ }^{18}$ (por. Siegel, 2009: 70; Schalock, 2010: 63).

Poniżej zaprezentuję oferowane rodzaje wsparcia zapobiegawczego odnoszące się do relacji pomiędzy rodzicem i/lub opiekunem dziecka zagrożonego niepełnosprawnością intelektualną i/lub dziecka z niepełnosprawnością intelektualną ${ }^{19}$. Będę je przedstawiała kolejno w odniesieniu do okresu prenatalnego, perinatal-

18 Mary Main w ramach badań nad przywiązaniem prowadzonych z Carol George oraz Nancy Kaplan „,[o]dkryły, ze wzorzec opowiadania przez rodzica «historii» swego wczesnego życia w rodzinie w ramach na wpół ustrukturyzowanego wywiadu można skorelować z klasyfikacją jego dziecka dokonaną na podstawie «sytuacji obcości» Ainsworth" (Siegel, 2009: 70). W rezultacie powyższych badań zostało opracowane narzędzie badawcze o nazwie Adult Attachment Interview (AAI). Obecnie badania z wykorzystaniem AAI są prowadzone na całym świecie (Siegel, 2009: 70).

19 Kiedy będę mówiła o niepełnosprawności intelektualnej, będę miała na uwadze niepełnosprawność intelektualną w stopniu lekkim, umiarkowanym, znacznym i głębokim. Poznawczo ciekawy były namysł nad specyfiką wsparcia oferowanego rodzicom i/lub opiekunom modyfikowanym stopniem jego niepełnosprawności. 
nego i postnatalnego życia dziecka z jednoczesnym uwzględnieniem konkretnych przykładów wsparcia zapobiegawczego.

Nie podlega jakiejkolwiek dyskusji fakt, że w okresie prenatalnym rozwoju dziecka zagrożonego niepełnosprawnością wsparcie powinno być oferowane ich rodzicom (por. Kopeć, 2005). Należy pamiętać, że rodzice oczekujący dziecka zagrożonego niepełnosprawnością intelektualną nie są grupą jednorodną. Można w niej wyróżnić rodziców, którzy (Kopeć, 2005: 30-34):

- po uzyskaniu wyników badań prenatalnych, potwierdzających nieprawidłowości w rozwoju dziecka, chcą podjąć decyzję co do dalszych jego losów: aborcja versus decyzja na bycie rodzicem dziecka prawdopodobnie dotkniętego niepełnosprawnością intelektualną;

- zostali poinformowani o tym, że po urodzeniu dziecka jest bardzo duże prawdopodobieństwo jego śmierci z powodu wad letalnych lub rozwojowych, wrodzonych, zniekształceń oraz aberracji chromosomowych (WRWZAC) (Dangel, 2010: 81-82);

- dowiedzieli się, że dziecko, które przyjdzie na świat, będzie dzieckiem z niepełnosprawnością uwarunkowaną genetycznie, np. z zespołem Downa;

- zostali poinformowani, że dziecko będzie operowane od razu po urodzeniu z powodu występujących wad rozwojowych stwierdzonych w trakcie badań prenatalnych.

Każdej z wyżej wymienionych grup rodziców powinno być oferowane wsparcie zapobiegawcze, które, moim zdaniem, będzie miało istotny wpływ na kształtowanie się relacji pomiędzy rodzicem a jego dzieckiem, nawet wówczas, gdy rokowania co do przeżycia dziecka są złe.

W okresie perinatalnym życia dziecka zagrożonego niepełnosprawnością intelektualną wsparcie zapobiegawcze powinno być oferowane przede wszystkim tym rodzicom, których dziecko z powodu WRWZAC umrze. Powinno ono pojawiać się, między innymi, w sytuacjach: a) podejmowania decyzji dotyczącej zaprzestania podtrzymywania życia dziecka za wszelką cenę; b) podejmowania decyzji o tym, że organy ich dziecka mają być przekazane innemu dziecku (Kopeć, 2005: 32).

W okresie postnatalnym życia dziecka dla relacji pomiędzy nim a jego rodzicem najistotniejsze są pierwsze lata życia (por. Cozolino, 2004; Czub, 2005: 67-93; Siegel, 2009; Gerhardt, 2010). Dlatego, mając na uwadze relację, przede wszystkim w tym okresie wsparcie zapobiegawcze powinno być oferowane rodzicom i/lub opiekunom dziecka zagrożonego niepełnosprawnością intelektualną i/ lub z niepełnosprawnością intelektualną. Należy bowiem pamiętać, że zagrożenie niepełnosprawnością intelektualną, jak również niepełnosprawność intelektualna dziecka wymaga od jego rodziców bardzo dużych umiejętności rodzicielskiej, które pozwolą na nawiązanie relacji z dzieckiem i trwanie w niej w taki sposób, że bę- 
dzie ono satysfakcjonujące dla obu partnerów interakcji. Bowiem „wrodzone dyspozycje dziecka ${ }^{20}$ mogą $\mathrm{w}$ mniejszym lub większym stopniu utrudniać właściwą interpretację płynących od niego sygnałów, ale decydujące znaczenie dla jakości relacji ma zachowanie opiekuna podejmowane jako reakcja na te sygnały. Ostatecznie to on decyduje, kiedy i jak będzie przebiegać interakcja (podkreślenie wł.) "21 (Czub, 2005: 81). Dlatego tak ważne jest wsparcie zapobiegawcze oferowane rodzicom i/lub opiekunom dziecka zagrożonego niepełnosprawnością lub dziecka z niepełnosprawnością intelektualną, którego egzemplifikacją powinna być oferta szkoleniowa dotycząca przede wszystkim dwóch obszarów problemowych: pierwszego, związanego $\mathrm{z}$ definiowaniem przez rodzica konkretnych problemów bycia $\mathrm{w}$ relacji ze swoim dzieckiem oraz przejawów (nie)radzenie sobie $\mathrm{z}$ nimi ${ }^{22}$. Mógłby on być powiązany $\mathrm{z}$ oddziaływaniem terapeutycznym dla tych rodziców i/ lub opiekunów, którzy wykazywaliby zainteresowanie własną terapiąa ${ }^{23}$; drugiego, związanego z procesami: a) godzenia się ze stratą „idealnego dziecka”, b) godzenia się z niepełnosprawnością „dziecka realnego"24 (por. Zalewska, 1998); trzeciego, związanego z podnoszeniem kompetencji rodzicielskich istotnych dla przebiegu

${ }^{20}$ Obok wrodzonych dyspozycji dziecka można również wymienić również zagrożenie niepełnosprawnością intelektualną oraz niepełnosprawność intelektualną.

${ }^{21}$ Spostrzeżenie to potwierdzają przeprowadzone przez van den Boom badania (Czub, 1005: 81). Autorka wyłoniła grupę stu niemowląt w ciągu pierwszych piętnastu dni po narodzinach, które przejawiały wrodzona skłonność do reagowania afektem negatywnym. Dzieci podzielono na dwie grupy, które liczyły pięćdziesiąt niemowląt. Matki niemowląt należących do jednej z tych grup uczestniczyły w programie szkoleniowym, którego celem było podniesienie kompetencji opiekuńczych (Czub, 1005: 81). „Program ten obejmował trzy dwugodzinne wizyty w domach, pomiędzy szóstym a dziewiątym miesiącem życia dziecka, podczas których zwiększano wrażliwość matek i wspomagano ich zdolności do właściwego odczytywania zarówno negatywnych, jak i pozytywnych sygnałów niemowlęcia, a następnie odpowiedniego reagowania na nie. (...). Okazało się, że program działań wspomagających kompetencje opiekuńcze istotnie zmienił zachowanie matek w relacji z dziećmi" (Czub, 1005: 81-82).

${ }^{22}$ Uważam, że autorefleksja dotycząca swojego bycia z własnym dzieckiem w obecności psychologa pozwoliłaby na wyłonienie tych problemów rodzica z relacją, które są egzemplifikacją transmisji międzypokoleniowego wzorca przywiązania charakterystycznego dla biografii rodzica (por. Czub, 2005; Siegel, 2009).

${ }^{23}$ Należy pamiętać, że w wyniku terapii lub kontaktów osobistych możliwe jest przejście z niespójnego do bardziej zintegrowanego stanu umysłu, który jest predyktorem rozwoju relacji pomiędzy rodzicem a dzieckiem (Siegel, 2009: 104). „(...) «nabyty» status (nazwa typu relacji przywiązania-uwaga wł.) jest czymś więcej niż umiejętnością czysto werbalną; osoby te potrafią także przejść od «słów do czynu» i nawiązać emocjonalną więź z własnym dziećmi, mimo że nie miały takich doświadczeń we własnym dzieciństwie. Możemy w istotny sposób przysłużyć się temu i przyszłym pokoleniom, umożliwiając sobie nawzajem osiagnięcie bardziej refleksyjnego, zintegrowanego funkcjonowania, które sprzyja ufnym relacjom przywiązaniowym" (Siegel, 2009: 104; por. Cozolino, 2004).

${ }^{24}$ Należy pamiętać, że oba procesy mogą facylitować pojawienie się depresji u rodziców (por. Pisula, 2003, 2007). 
relacji pomiędzy rodzicem i/lub opiekunem a dzieckiem zagrożonym niepełnosprawnością intelektualną lub z niepełnosprawnością intelektualną. Ich podnoszenie stwarza bowiem nie tylko większe możliwości pojawienia się u dziecka ufnego przywiązania, ale również widzenie w dziecku przez jego rodziców OSOBY, a nie tylko, co niestety często się zdarza, obiektu oddziaływań pielęgnacyjnych czy rehabilitacyjnych. Dlatego też podnoszenie kompetencji rodzicielskich powinno dotyczyć, między innymi:

- umiejętności opiekuńczych, takich jak: karmienie, kąpiel, które w odniesieniu do dziecka zagrożonego niepełnosprawnością intelektualną lub z niepełnosprawnością intelektualną są dla rodzica i/lub opiekuna niejednokrotnie bardzo dużym wyzwaniem;

- wspomagania odczytywania sygnałów wysyłanych przez dziecko, zarówno tych pozytywnych, jak i negatywnych (por. Fröhlich, Simon, 2008);

- wspomaganie dostrzegania przejawów osobowego Ja dziecka, nawet, a może przede wszystkim, tych rudymentarnych, oraz traktowania ich z należytą uważnością (por. Fröhlich, 1991).

Powyżej przedstawione możliwości podnoszenia kompetencji rodzicielskich są egzemplifikacją, jedną z wielu oczywiście, wsparcia zapobiegawczego istotnego dla dziecka jak również jego rodziców i/lub opiekunów.

\section{Zakończenie}

W koncepcji zapobiegania niepełnosprawności intelektualnej zaproponowanej przez Schalocka i jego zespół (2010) na uwagę zasługuje:

- po pierwsze: wielopłaszczyznowe ujmowanie zapobiegania niepełnosprawności intelektualnej;

- po drugie: wprowadzenie pojęcia wsparcia zapobiegawczego, którego beneficjentem jest zarówno osoba z niepełnosprawnością intelektualną, jak i osoby z jej najbliższego otoczenia;

- po trzecie: zwrócenie uwagi na czynniki ryzyka niepełnosprawności intelektualnej ujmowane nie tylko z perspektywy nauk medycznych i biologicznych, ale również z perspektywy psychologii, psychologii rozwojowej oraz socjologii;

- po czwarte: ukazanie ważności relacji pomiędzy rodzicem a jego dzieckiem z niepełnosprawnością intelektualną.

Myślę, że z uwagi na powyższe warto zastanowić się nad implementacją koncepcji zapobiegania niepełnosprawności intelektualnej zaproponowanej przez Schalocka i jego zespół (2010) na grunt polskiej pedagogiki specjalnej. 


\section{Literatura}

Deutsch Smith D. (2008). Pedagogika specjalna, t. 1. Przeł. T. Hołówka, A.P. Zakrzewski. Warszawa

Bronfenbrenner U. (2005). The Bioecological Theory of Human Development, [W:] Making Human Beings Human: Bioecological Perspectives on Human Development, 3-15. (Ed.) U. Bronfenbrenner. Thousand Oaks

Bronfenbrenner U. (1979). The Ecology of Human Development. Cambrige

Budajczak M. (2008). Edukacja domowa. [W:] Encyklopedia pedagogiczna XXI wieku. (Red.) T. Pilch, T. Żak. Warszawa

Cozolino L.J. (2004). Neuronauka w psychoterapii. Budowa i przebudowa ludzkiego mózgu. Przeł. J. Gilewicz. Poznań

Czub T. (2005). Wiek niemowlęcy. Jak rozpoznać ryzyko i jak pomagać? [W:] Psychologiczne portrety człowieka. Praktyczna psychologia rozwojowa, 67-93. (Red.) A.I. Brzezińska. Gdańsk

Dangel T. (2010). Wady letalne u płodów i noworodków. Opieka paliatywna jako alternatywa wobec eugenicznej aborcji, eugenicznego dzieciobójstwa i uporczywej terapii. [W:] Bioetyka w zawodzie lekarza, s. 81-101. (Red.) W. Chańska, J. Hartman. Warszawa

Fröhlich A., Simon A. (1991). Basale Stimulation. Düsseldorf

Fröhlich, A., Simon, A. (2008). Gemeinsamkeiten entedecken. Mit schwerbehinderten Kindern kommuniziren. Düsseldorf

Gerhardt S. (2010). Znaczenie miłości. Jakie uczucia wpływaja na rozwój mózgu. Przeł. B. Radwan. Kraków

Kopeć D. (2005). Pedagog specjalny w obliczu problemów rodziców oczekujących dziecka zagrożonego niepetnosprawnością. [W:] Niepełnosprawni, osieroceni, niedostosowani. Problemy profilaktyki i wsparcia we współczesnej pedagogice, 29-35. Red. I. Fornalik. Jelenia Góra

Kościelska M. (1995). Oblicza upośledzenia umysłowego. Warszawa

Kościelska M. (1998). Trudne macierzyństwo. Warszawa

Krause A. (2009). Upośledzenie umysłowe, niepetnosprawność umysłowa czy niepetnosprawność intelektualna. [W:] Pedagogika specjalna. Różne poszukiwania - wspólna misja. Pamięci Profesora Jana Pańczyka, 63-70. Red. M. Bielska-Łach. Warszawa

Mowszet K., Hutyra T. (2008). Dziecko z fenyloketonuria. [W:] Dzieci chore, niepelnosprawne i z utrudnieniami w rozwoju, 201-216. Red. B. Cytowska, B. Winczura, A. Stawarski. Kraków

Olszewski S., Parys K., Trojańska, M. (red.) (2012). Przestrzenie życia osób z niepełnosprawnością. Kraków

Pisula E. (2003). Autyzm i przywiązanie. Studia nad interakcjami dzieci zautyzmem i ich matek. Gdańsk

Pisula E. (2007). Rodzice i rodzeństwo dzieci z zaburzeniami rozwoju. Warszawa

Ridley M. (2001). Genom. Autobiografia gatunku w 23 rozdziałach. Przeł. M. Koraszewska. Poznań

Salvador-Carulla L., Reed, G.M., Vaez Azizi, L.M. (et al.). (2011). Intellectual Developmental Disorders: Towards a New Name, Definitione and Framework for „Mental Retardation/Intellectual Disability in ICD-11. "World Psychiatry" 10: 175-180.

Schalock R.L., Borhwick-Duffy A., Luckasson R. (et al.). (2010). Intellectual Disability. Definitione, Classification and Systems of Supports. The AAIDD Ad Hoc Committee on Terminology and Classification. 11th ed. Washington 
Schalock R.L., Luckasson, R., Shogren, K., Bortwick-Duffy A. (2007). The Renaming of Mental Retardation: Understanding the Change to the Term Intellectual Disability. "Intellectual and Developmental Disabilities" 45 (2): 116-124

Siemińska M.J. (2010). Genetyczne związki, rodzinne powiązania i społeczne więzi: o naturze zależności w obliczu wiedzy genetycznej. [W:] Bioetyka w zawodzie lekarza, 81-101. Red. W. Chańska, J. Hartman. Warszawa

Siegel D.J. (2009). Rozwój umysłu. Jak stajemy się tym, kim jesteśmy. Przeł. R. Andruszko. Kraków

Stawicka M. (2008). Autodestruktywność dziecięca w świetle teorii przywiązania. Poznań

Wehmeyer, M., Buntinx, W., Lachapelle, Y., Luckasson, R., Schalolck, R. (et al.), (2008). The Intellectual Disability Construct and its Relation to Human Functioning. "Intellectual and Developmental Disabilities" 46 (4): 311-318.

Wlazło M. (2005). Upośledzenie czy niepetnosprawność - o znaczeniu, funkcjach i podstawach naukowych nazewnictwa w pedagogice specjalnej. [W:] Pedagogika specjalna - aktualne osiagnięcia i wyzwania, 130-135. Red. T. Żółkowska. Szczecin

Zalewska M. (1998). Dziecko w autoportrecie z zamalowana twarza. Warszawa

\section{Prevention of Intellectual Disability in the Light of the Considerations of the American Association on Intellectual and Developmental Disabilities (AAIDD)}

\section{Summary}

The American Association on Intellectual and Developmental Disabilities ad Hoc Committee on Terminology and Classification (Schalock and others, 2010) examines the prevention of a person's intellectual disability in the context of three different aspects of which attention is paid to a) the degree of prevention of intellectual disability - aspect one; b) the influence of factors determining intellectual disability in the course of a person's lifetime - aspect two; c) prevention as a form of support, so called preventive support - aspect three (Schalock and others, 2010: 123-129). Within the scope of the first aspect, three degrees of intellectual disability prevention may be distinguished: primary, secondary and tertiary. The primary prevention of intellectual disability focuses on eliminating all possibility of intellectual disability ie. providing support for pregnant women with alcohol dependency in order to help them to remain alcohol free. The secondary prevention mainly concerns persons who are suffering from a particular disability, most frequently a genetic condition, which may not be directly prevented. Within the scope of tertiary prevention, the use of strategies should be considered which may decrease but not eliminate the consequences of disabilities in a person, as well as the consequences of the person's intellectual disability. What is analyzed in the context of secondary prevention is the influential factor conditioning the intellectual disability in the course of a person's lifetime. The Shalock's team distinguished four risk factor categories of intellectual disability, namely: a) biomedical, regarding the biological aspect of a person's functioning; b) social, connected with social (relationship-based) aspect of human functioning; c) behavioral, connected with the functioning of parents and/or guardians which may have a negative effect on a child; d) educational, connected with the availability of educational support which affects parental knowledge and skills (Schalock and others, p. 61 and 131). The concept of tertiary prevention 
concerns the form of support. Schalock and his team, in addition to the general understanding of support as represented by AAIDD, formerly AAMR, (The American Association on Mental Retardation) introduced the concept of preventive support (2010: 128-131). The constructed model of preventing intellectual disability is referred to as multifactorial and intergenerational (Schalock and others, 2010, p.130). It is extremely crucial for educational practice and theory that Schalock and his team highlight the parent-child relationship which serves as the context for providing preventive support in order to eliminate the possibility of intellectual disability of a child (2010, p.130). Preventive support should be offered to parents during the prenatal period of a child who remains at risk of developing an intellectual disability. It must be kept in mind that those parents who are expecting a child that is at risk of developing intellectual disability do not constitute a homogeneous group. Hence, we may distinguish parents, who (Kopeć, 2005: 30-34): a) on receiving the results of prenatal examination that confirm irregularities in the child's development may wish to make decisions about the further course of action: abortion versus the decision to be the parent of a child that will be a probable sufferer of intellectual disability; b) have been informed that there is a high risk of mortality after the child's birth due to its critical defects or developmental, inborn defects, deformities and chromosomal aberrations (WRWZAC) (Dangel, 2010: 81-82); c) have become aware that the child they are expecting will suffer from a genetically conditioned disability ie. a child with Down's syndrome; d) who have been informed that the child will have to be operated on immediately after birth, due to the presence of developmental defects that were determined in the course of prenatal examinations. During the perinatal period of a child at risk of developing an intellectual disability, preventive support should be offered especially to those parents whose child is expected to die as a result of WRWZAC. The support should also be provided in the cases of: a) taking the decision to refuse or remove life support for the child; b) taking the major decision of organ donation to another child (Kopeć, 2005: 32). In the postnatal life of a child the early years of its life are the most crucial for forming the bond between the child and its parents. Therefore, it is precisely during this period that preventive support should be offered to parents and/or guardians of a child that is at risk of developing an intellectual disability or has a pre-existing intellectual disability. 